\title{
Diversification and genetic structure of the western-to-eastern progression of European Phaseolus vulgaris L. germplasm
}

\author{
Barbara Pipan * (D) and Vladimir Meglič
}

\begin{abstract}
Background: Common bean (Phaseolus vulgaris L.) is the most important food legume for direct human consumption around the world, as it represents a valuable source of components with nutritional and health benefits.

Results: We conducted a study to define and explain the genetic relatedness and diversification level of common bean (Phaseolus vulgaris L.) germplasm from Portugal to Ukraine, along a western-to-eastern line of southern European countries, including Poland. This was based on the P. vulgaris genetic structure, and was designed to better describe its distribution and domestication pathways in Europe. Using the multi-crop passport descriptors that include geographic origin and different phaseolin types (corresponding to the Mesoamerican and Andean gene pools), 782 accessions were obtained from nine gene banks and 12 geographic origins. We selected 33 genome/ gene-related/ gene-poolrelated nuclear simple sequence repeat markers that covered the genetic diversity across the $P$. vulgaris genome. The overall polymorphic information content was 0.800 . Without specifying geographic origin, global structure cluster analysis generated 10 genetic clusters. Among the PvSHP1 markers, the most informative for gene pool assignment of the European P. vulgaris germplasm was PVSHP1-B. Results of AMOVA show that $89 \%$ of the molecular variability is shared within the 782 accessions, with $4 \%$ molecular variability among the different geographic origins along this western-to-eastern line of southern Europe (including Poland).

Conclusions: This study shows that the diversification line of the European P. vulgaris germplasm followed from the western areas of southern Europe (Portugal, Spain, Italy, Slovenia) to the more eastern areas of southern Europe. This progression defines three geographically separated subgroups, as the northern (Poland, Ukraine, Romania), southern (Albania, Bulgaria), and central (Bosnia and Herzegovina, Serbia, Hungary) areas of eastern Europe.
\end{abstract}

Keywords: Common bean, SSR markers, Geographic origin, Gene pool, Gene bank, Genetic clusters, Genetic diversity, European accessions

\section{Background}

The common bean (Phaseolus vulgaris L.) is the most important food legume throughout the world for direct use (for review, see [1]). P. vulgaris is also a rich source of polyphenolic compounds that have numerous healthpromoting properties [2].

In the last decade, several thousand accessions of Phaseolus have been collected ever more intensively in different parts of Europe, and these are stored in national gene banks. At present, the Phaseolus database in the

\footnotetext{
* Correspondence: barbara.pipan@kis.si

Crop Science Department, Agricultural Institute of Slovenia, Hacquetova ulica 17, Sl-1000 Ljubljana, Slovenia
}

(c) The Author(s). 2019 Open Access This article is distributed under the terms of the Creative Commons Attribution 4.0 International License (http://creativecommons.org/licenses/by/4.0/), which permits unrestricted use, distribution, and

web-based European Search Catalogue for Plant Genetic Resources (EURISCO) contains over 50,000 records, which includes more than 40,000 characterisation and evaluation records, and 585 photographs [3]. Due to the distributions of the wild forms, a number of studies have suggested that $P$. vulgaris has gone through at least two isolated and independent domestication processes. Consequently, two independent events in the Americas have been documented (i.e., in Mesoamerica and the Andes) $[1,4,5]$, from where the two major domesticated gene pools originated (for review, see [6]).

Phaseolin is the major seed storage protein of common bean, and it is an important molecular marker [7]. For Mesoamerican origin, the specific types of phaseolin are 
Sanilac, as S type, Middle America, as M type, and Boyacá, as $B$ type $[7,8]$. The predominant phaseolin type for the Andean gene pool is Tendergreen, as T type, followed by Contender, as $\mathrm{C}$ type, which can also indicate a mixed origin with the Mesoamerican form. Huevo de Huanchaco, or $\mathrm{H}$ type, phaseolin also belongs to the Andean group. The three indel spanning markers SHP1-A, SHP1-B and SHP1-C were used for identification of the gene pool of origin, as Nanni et al. [9] reported that for 91 P. vulgaris accessions, no Ib haplotypes were shared between the Mesoamerican and Andean gene pools.

Based on evaluations of morphological variation and microsatellite diversity, Rendón-Anaya et al. [10] and others [11-14] reported that the accompanying domestication processes, such as increased genetic diversity of the domesticated varieties, arose from domestication bottlenecks and hybridisation events between the wild and domesticated populations. The wild progenitor of common bean has an exceptionally large distribution, from northern Mexico to north-western Argentina, which is unusual among wild progenitors of today's crops [15]. These same recent studies also report on the molecular ecology, selection and adaptation in the drought-related genes/ polymorphisms in wild and cultivated common bean [16-18]. Moreover, two recent studies have reported that the genome-wide association in wild common bean predicts widespread divergent adaptation to drought $[19,20]$, and that species divergence in Phaseolus beans has led to parallel signatures of adaptation and domestication [21]. Genetic diversity assessments and the structure of Phaseolus coccineus L. clearly differentiate between the European and Mesoamerican gene pools, which infers a moderate to strong cytoplasmic bottleneck that followed the expansion of $P$. coccineus into Europe through multiple domestication events [22].

For European P. vulgaris germplasm, Carović-Stanko et al. [8] reported that the main group of European accessions were of Andean origin ( $68 \%)$, with fewer of Mesoamerican origin ( 27\%). The rest of the European accessions represented putative hybrids between these two gene pools. Additionally, Maras et al. [23] indicated that Andean genotypes were more prevalent than Mesoamerican in the countries from the five former Yugoslav republics (except for Macedonia) that constituted the western Balkans. This kind of trend might be the consequence of the political regulation within these countries in the past. Both of these studies used combinations of molecular and seed-protein markers. However, simple sequence repeat (SSR) markers have also been shown to be one of the most informative, efficient and costeffective tools for population genetics studies of different agronomically important plant species [23-32]. Recently, Campa et al. [33] published a study on Spanish $P$. vulgaris diversity (308 local lines, mainly used for snap consumption), where they indicated that $70 \%$ of the lines were associated with the Andean gene pool. The panel was characterised by 3099 single nucleotide polymorphism (SNP) markers that were obtained through genotyping-by-sequencing, which revealed wide genetic diversity and low levels of redundant material within the panel [33]. Moreover, the genetic diversity and population structure in the common bean in Turkey was examined using diversity arrays technology (DArT) markers, which revealed two main populations, as A (predominant) and B, and five unclassified genotypes. These represented three meaningful heterotic groups for breeding purposes [34]. Thus, current advances in molecular technologies can provide evidence of the human selection that has acted on numerous loci during and after crop domestication [35]. Moreover, with its different adaptation abilities, common bean might be suitable for organic farming systems [36].

In the present study, we genotyped 782 accessions from 12 (country-based) areas of geographic origin from Portugal to Ukraine, along a western-to-eastern line of southern European countries (including Poland) using 33 loci: 24 markers for diversity levels; three markers related to gene pool assignment; and six gene-related markers. The main objectives of this study were: (i) to identify and collect the most geographically different $P$. vulgaris accessions from these European areas; (ii) to obtain global diversification levels and the genetic structure of $P$. vulgaris from these European areas without specifying geographic origin; (iii) to define the genetic relatedness of $P$. vulgaris accessions from these European areas in terms of their geographic origins; (iv) to detect allelic diversity of $P \nu \mathrm{SHP} 1$ markers related to gene-pool assignment of the germplasm from these European areas; and (v) to identify the genetic potential of the germplasm from these European areas for association mapping studies, to help with the identification of new sources of genetic diversity. The data from the present study can be used mainly to investigate the levels of genetic diversity and the genetic structure of common bean from these 12 European areas, and to acquire new knowledge about its expansion processes and related diversification in Europe. This knowledge can now be used for common bean breeding, especially in terms of its adaptation to different environments.

\section{Results}

Geographic origins of the genotyped accessions

On a basis of the initial screening using multi-crop passport descriptors, the full set of samples comprised 782 accessions from 12 geographic origins: Albania (23), Bosnia and Herzegovina (57), Bulgaria (19), Hungary (277), Italy (20), Poland (18), Portugal (8), Romania (14), 
Serbia (218), Slovenia (97), Spain (11) and Ukraine (20) (Additional file 4: Table S1; numbers of assessed accessions within each country are included in Fig. 4b). For 63 of the accessions from Slovenia, Italy, Portugal and Spain, the information on phaseolin type included $\mathrm{C}$ type (23), B type (1), H type (1), S type (18) and T type (20), which served as an orientation for the gene-pool assignment (Additional file 4: Table S1).

\section{Diversification level and genetic structure for the western-to-eastern line of southern European $P$. vulgaris germplasm}

Within the whole set of 782 accessions, the overall number of alleles with frequency $\geq 5 \%$ was 5.39 , and the number of private alleles was 27.52. All of the SSR markers were polymorphic, and the whole set of 782 accessions showed statistically significant $H W E$ deviation for all loci $(p<0.001)$. Moreover, combining genetic variability parameters among loci and other measures of population genetics did not indicate any deviations that might be due to a significant frequency of null alleles. The genetic variability defined by the expected heterozygosity $\left(H_{e}\right)$ for the whole collection was 0.822 . Overall the PIC reached 0.800 , with a mean of 6.842 effective alleles per locus, and a mean of 22.767 for $\operatorname{Ar}$ (Table 1). The most informative SSR markers (i.e., with $P I C>0.9$ ) were GATS91 (PIC $\left.=0.923 ; H_{e}=0.928 ; N e=13.749\right)$, BMd001 $\left(P I C=0.917 ; H_{e}=0.923 ; N e=12.801\right)$, ATA006 $\left(P I C=0.905 ; \quad H_{e}=0.912 ; \mathrm{Ne}=11.346\right)$ and SSR-IAC62 $\left(P I C=0.925 ; H_{e}=0.930 ; \mathrm{Ne}=14.137\right)$, which defined the highest $H_{e}(>0.9)$ and the highest $N e(>11)$. For these loci, $A r$ was high ( $>23$ ). Locus BMd001 had the overall highest $A r$ (43.451) and $I$ (2.944). The highest $F$ was obtained for ATA007 (0.663), and the lowest $F$ for locus BM210 (- 0.794). On the other hand, the least polymorphic loci were SSR-IAC167 and BM210, which had the lowest $H_{e}(0.585 ; 0.540$; respectively), PIC (0.542; $0.434), \mathrm{Ne}(2.405 ; 2.172)$ and $I(1.215 ; 0.867)$ (Table 1$).$

The global distribution in the FCA for these accessions from western-to-eastern areas of southern Europe defined four factors with a 5.35\% level of integrity. In general, three main groups of accessions were defined, which corresponded to the Mesoamerican and Andean subgroups, plus a subgroup with mixed origins, and an out-group that only included the $P$. coccineus accession (Fig. 1). To link the membership of each group, the standard accessions with a known type of phaseolin were each used for orientation. Therefore, the accessions with phaseolin $\mathrm{T}$ type were assigned to the typical Andean gene pool, the accessions with phaseolin $S$ type to the typical Mesoamerican gene pool, and the accessions with phaseolin $C$ type were the members of the subgroup with mixed origins extracted from the Andean subgroup and leading to the Mesoamerican subgroup (Fig. 1, yellow symbols within each cluster). Based on the phylogenetic relationships between the whole set of accessions (Additional file 2: Figure S2), analysis of the three main groups was carried out according to Nei's standard genetic distance [45] and the UPGMA clustering method.

When the Bayesian/ Evanno approach was applied without specifying the population of origin, 10 genetic clusters were generated from the admixture model for the 782 accessions (Additional file 1: Figure S1). The means of the calculated genetic distances among these 10 clusters were from 0.681 to 0.812 , which corresponded to F statistic (Fst) from 0.013 to 0.150 .

\section{Genetic relatedness among the different geographic origins}

Determination of the genetic relatedness among the 12 geographic origins was performed on the basis of the data obtained for all 33 of the loci. The results of the cluster analysis using the information on the gene-bank origins of the accessions showed that there were only three genetic clusters, which showed genetic diversities (across the genome diversity) of $0.749,0.738$ and 0.772 . Moreover, the molecular variability of the $P$. vulgaris accessions among nine gene banks was $3 \%$, while the other $97 \%$ of the P. vulgaris molecular variability of the gene pools did not account for significant structure (AMOVA, $p>0.010$ ) (Additional file 6: Table S3).

Considering the information about the geographic origins (i.e., the 12 countries) instead of the gene-bank origins, seven genetic clusters were generated using the Bayesian/ Evanno algorithm (Additional file 3: Figure S3). To clarify these analyses, the same algorithm and the same criteria for choosing the optimum number of clusters was used in each, but with different original information given in the input matrix (i.e., without specifying the population of geographic origin [only one/ European origin]; using the information of the gene-bank origins [eight gene-bank origins]; and specifying the geographic origin [12 geographic origins]); these thus provided different results (i.e., different numbers of genetic clusters). The numbers of genetic clusters that were generated on the basis of the genetic structure with the specification of the population of origin of the accessions varied from three (Hungary) to 11 (Italy, Poland) (Table 3). The mean distances between the accessions in the same clusters varied from 0.669 to 0.808 . The results of the AMOVA showed that $89 \%$ of the molecular variability was shared within the 782 accessions, and that there was only $4 \%$ molecular variability among the different geographic origins, which did not define significant structure from these western-to-eastern areas of southern Europe (Table 2).

Regarding the pairwise comparisons of accessions within each geographic origin, the highest Nei's genetic identities were seen both between neighbouring countries, such as 
Table 1 Parameters of the genetic variability of the 782 accessions from the western-to-eastern areas of southern Europe, across the 33 loci

\begin{tabular}{|c|c|c|c|c|c|c|}
\hline Locus & $\begin{array}{l}\text { Expected } \\
\text { heterozygosity }\left(H_{e}\right)\end{array}$ & $\begin{array}{l}\text { Polymorphic information } \\
\text { content }\end{array}$ & $\begin{array}{l}\text { Allelic richness } \\
\text { (Ar) }\end{array}$ & $\begin{array}{l}\text { Number of effective } \\
\text { alleles (Ne) }\end{array}$ & $\begin{array}{l}\text { Shannon's information } \\
\text { index (I) }\end{array}$ & $\begin{array}{l}\text { Fixation } \\
\text { index }(F)\end{array}$ \\
\hline$\overline{\mathrm{ATA}^{2} 03^{* a}}$ & 0.879 & 0.867 & 27.709 & 8.212 & 2.446 & 0.198 \\
\hline ATA004 ${ }^{* a}$ & 0.849 & 0.834 & 24.000 & 6.551 & 2.326 & 0.362 \\
\hline ATA005 ${ }^{* a}$ & 0.843 & 0.828 & 30.132 & 6.362 & 2.392 & -0.040 \\
\hline ATA007*a & 0.804 & 0.779 & 24.845 & 5.080 & 2.040 & 0.663 \\
\hline ATA016 ${ }^{* a}$ & 0.790 & 0.762 & 17.147 & 4.752 & 1.873 & -0.066 \\
\hline GATS91 ${ }^{* c}$ & 0.928 & 0.923 & 32.292 & 13.749 & 2.890 & -0.060 \\
\hline $\mathrm{ATAOO2}^{* a}$ & 0.858 & 0.845 & 30.798 & 6.982 & 2.452 & 0.044 \\
\hline $\mathrm{BM} 172^{{ }^{*} \mathrm{C}}$ & 0.894 & 0.885 & 35.118 & 9.411 & 2.686 & 0.097 \\
\hline BMd001*b & 0.923 & 0.917 & 43.451 & 12.801 & 2.944 & 0.019 \\
\hline ATA020 ${ }^{* a}$ & 0.882 & 0.872 & 34.052 & 8.422 & 2.596 & 0.288 \\
\hline Pv-ag004 ${ }^{* i}$ & 0.845 & 0.828 & 26.295 & 6.432 & 2.287 & -0.100 \\
\hline $\begin{array}{l}\text { SSR- } \\
\text { IAC167*h }\end{array}$ & 0.585 & 0.542 & 12.735 & 2.405 & 1.215 & 0.116 \\
\hline ATA010 ${ }^{* a}$ & 0.825 & 0.802 & 14.617 & 5.690 & 1.986 & 0.435 \\
\hline $\mathrm{BM} 155^{* \mathrm{C}}$ & 0.741 & 0.694 & 9.139 & 3.847 & 1.447 & -0.168 \\
\hline $\mathrm{BM} 170^{* \mathrm{C}}$ & 0.889 & 0.879 & 27.770 & 8.960 & 2.537 & -0.060 \\
\hline $\mathrm{BM} 183^{{ }^{*} \mathrm{C}}$ & 0.724 & 0.682 & 14.747 & 3.610 & 1.601 & -0.285 \\
\hline $\mathrm{BM} 210^{* \mathrm{C}}$ & 0.540 & 0.434 & 5.402 & 2.172 & 0.867 & -0.794 \\
\hline $\mathrm{BMd} 044^{* \mathrm{~b}}$ & 0.762 & 0.726 & 13.088 & 4.187 & 1.667 & 0.236 \\
\hline ATA009 $^{* a}$ & 0.901 & 0.893 & 23.516 & 10.083 & 2.593 & 0.179 \\
\hline ATA145 $5^{* a}$ & 0.796 & 0.781 & 22.613 & 4.888 & 2.162 & 0.431 \\
\hline $\mathrm{GA} 16^{* a}$ & 0.855 & 0.837 & 15.225 & 6.858 & 2.110 & 0.090 \\
\hline ATA006 ${ }^{* a}$ & 0.912 & 0.905 & 23.074 & 11.346 & 2.642 & 0.085 \\
\hline $\mathrm{BM} 157^{* \mathrm{c}}$ & 0.813 & 0.788 & 14.464 & 5.345 & 1.938 & 0.461 \\
\hline BMd042 & 0.857 & 0.842 & 24.054 & 6.977 & 2.312 & -0.104 \\
\hline ATA289*a & 0.773 & 0.743 & 20.694 & 4.391 & 1.861 & -0.239 \\
\hline PVSHP1-A ${ }^{* * * d}$ & 0.855 & 0.839 & 17.111 & 6.868 & 2.195 & -0.138 \\
\hline PvSHP1-B ${ }^{* * * d}$ & 0.856 & 0.838 & 16.937 & 6.911 & 2.093 & -0.132 \\
\hline PVSHP1C $C^{* * * d}$ & 0.849 & 0.833 & 16.159 & 6.615 & 2.173 & -0.004 \\
\hline $\mathrm{PvMO4}^{* * \mathrm{ff}}$ & 0.734 & 0.705 & 14.745 & 3.752 & 1.727 & 0.359 \\
\hline $\mathrm{PvM} 21^{* * f}$ & 0.753 & 0.724 & 17.757 & 4.047 & 1.752 & -0.279 \\
\hline PvM95 ${ }^{* * 9}$ & 0.779 & 0.752 & 28.173 & 4.511 & 1.980 & -0.208 \\
\hline SSR-IAC62 ${ }^{* * e}$ & 0.930 & 0.925 & 32.777 & 14.137 & 2.892 & 0.073 \\
\hline SSR-IAC66 ${ }^{* *} e^{-}$ & 0.895 & 0.885 & 40.677 & 9.449 & 2.671 & -0.061 \\
\hline Mean values & 0.822 & 0.800 & 22.767 & 6.842 & 2.162 & 0.042 \\
\hline
\end{tabular}

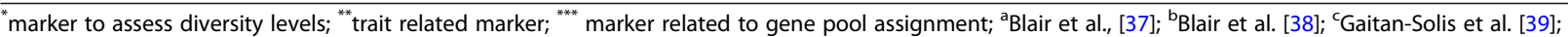
${ }^{\mathrm{d}} \mathrm{Nanni}$ et al. [9]; ${ }^{\mathrm{e} B e n c h i m o l}$ et al. [40]; ${ }^{\mathrm{f}} \mathrm{Hanai}$ et al. [41]; ${ }^{9} \mathrm{Hanai}$ et al. [42]; ${ }^{\text {h}} \mathrm{Campos}$ et al. [43]; ${ }^{\mathrm{i}}$ Yu et al. [44]

Poland and Ukraine (0.882) and Bosnia and Herzegovina and Serbia (0.892), and between non-neighbouring countries, such as Italy and Spain (0.810) (Fig. 2). The estimation of the gene flow among the geographic origins through the private allele method of Slatkin [46] was 0.541, and the corrected estimated value of Barton and Slatkin [47] was 0.401.

The accessions that originated from Hungary, Serbia and Slovenia did not show any deviations from HWE for any of the loci. The highest levels of genetic variability were seen for the Hungary, Italy, Poland and Slovenia accessions $\left(u H_{e}>0.8\right)$. Considering $A r$, the accessions from Serbia reached the higher level of fundamental genetic variation that is suitable for conservation $(\mathrm{Ar}=$ 1.678). Correspondingly, the highest proportion of molecular variability explained for PCoA (with the first three axes) was for the Serbia accessions (73.5\%), 


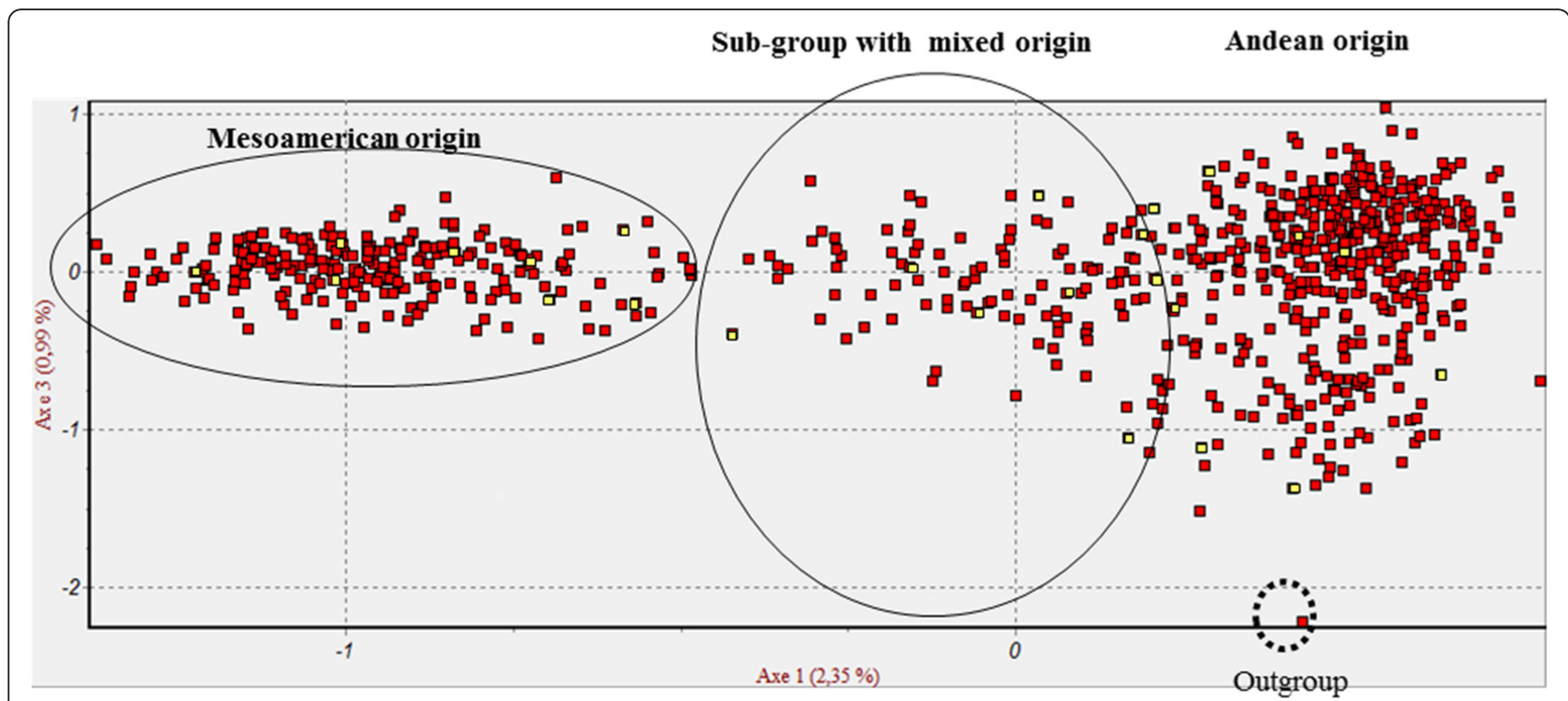

Fig. 1 Global factorial correspondence analysis distribution of the accessions from the western-to-eastern areas of southern Europe. Yellow symbols, accessions with known phaseolin type within each group

followed by the accessions from Bosnia and Herzegovina (71.0\%). Moreover, PCoA was performed within each country, and the proportions of explained genetic variability with the first three axes are given in Table 3. Regardless of the number of genetic clusters defined for each geographic origin, the mean $H_{e}$ across the clusters for each origin varied from 0.676 for the Albania accessions, to 0.809 for the Italy and Serbia accessions (Table 3). The loci that were without statistically significant deviations from HWE $(p>0.05)$ are given in Additional file 7: Table S4.

Considering the mean PIC, the applied set of 33 SSR markers was the most informative for the Hungary accessions (0.815), and the least informative for the Albania accessions (0.569) (Table 3).

\section{Allelic diversity of PvSPHP1 markers related to the gene- pool assignments}

Based on the known information about phaseolin types, 63 accessions were screened in detail at the PvSHP1-A, PvSHP1-B and PvSHP1-C loci, to determine whether there were any significant patterns related to the phaseolin types or the gene-pool assignments. In general, these three loci deviated from $H W E$ for the groups of all three of the main phaseolin types (i.e., C, S, T), with statistical significance seen $(p<0.01)$, except for PvSH1-C within the phaseolin $\mathrm{T}$ and $\mathrm{S}$ groups. Here, these markers can be used to distinguish between the phaseolin $\mathrm{T}$ and $\mathrm{S}$ types. In general, the accessions with phaseolin $C$ or $S$ types and phaseolin $\mathrm{C}$ or $\mathrm{T}$ types were clustered together, except for accessions IT4102T, PHA0107prB, PHA418siT and PHA318siT (Fig. 3).

For the geographic origins, no significant deviations from $H W E$ were seen for the marker PvSHP1-C for the Bulgaria, Albania and Portugal accessions, and for the marker PvSh1-A for the Spain accessions. The distribution pattern along the PvSHP1 markers generated two groups; from the main group of Andean origin (Fig. 4a, right) through the subgroup with mixed origin, to the main group of Mesoamerican origin (Fig. 4a, left), thus combining the accessions from all of the screened geographic origins (Fig. 4c).

As seen from Fig. 4a, the accessions from all of the geographic origins were distributed along the first two principal coordinates, with sharing of the same $P$.

Table 2 Analysis of molecular variance considering the geographic origins of the accessions

\begin{tabular}{lllllc}
\hline Source & $\begin{array}{l}\text { Degrees of } \\
\text { freedom }(\mathrm{df})\end{array}$ & $\begin{array}{l}\text { Sum of the } \\
\text { squared differences }\end{array}$ & Mean square & Estimated variance & $\begin{array}{l}\text { Percentage of } \\
\text { molecular variance }\end{array}$ \\
\hline Among geographic origins & 11 & 749.415 & 68.129 & 0.490 & $4^{*}$ \\
Among accessions & 770 & $10,987.300$ & 14.269 & 1.081 & 8 \\
Within accessions & 782 & 9467.500 & 12.107 & 12.107 & 89 \\
Total & 1563 & $21,204.215$ & & 13.678 & 100 \\
\hline
\end{tabular}

${ }^{*} p<0.01$ (F-statistics) 


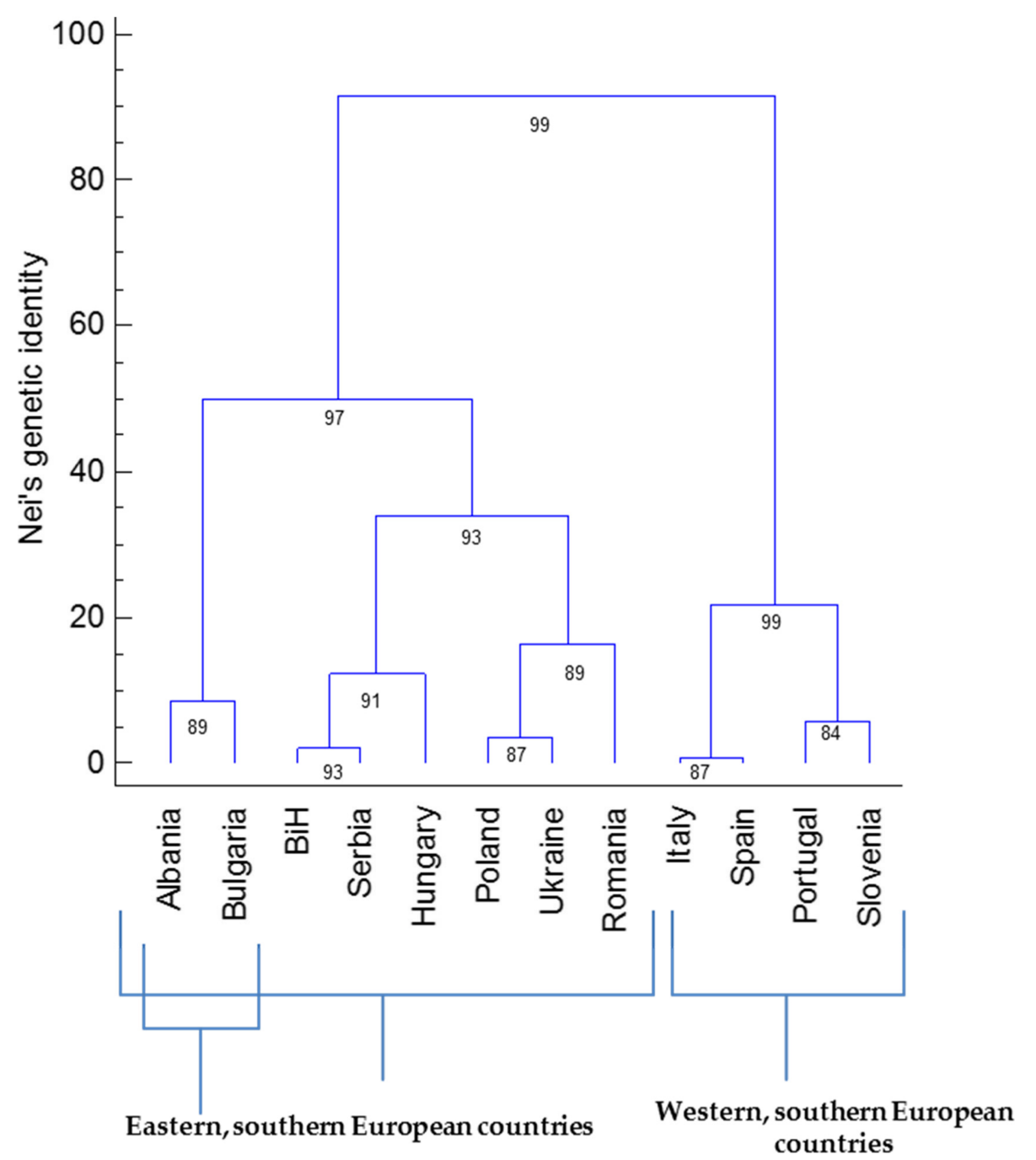

Fig. 2 Squared Euclidian dendrogram of the geographic relatedness according to the pairwise matrix of Nei's genetic identity and Ward's method with bootstrap support. BIH, Bosnia and Herzegovina

vulgaris germplasm from Andean to Mesoamerican, and to the subgroup with mixed gene pools. Detailed information on the basis of the PvSHP1 markers and PCoA distribution are presented in Fig. $4 \mathrm{~b}$, where the 12 pie charts superimposed on the geographic map show the breakdown of the three subgroups for each country. The background of Fig. 4b is keeping the information about the number of accessions (in brackets), to better present the analysed accessions from each geographic origin. As seen from Fig. 4b, the Andean origin is predominant in 10 European countries. The lowest level of Andean genotypes was for Spain (37.5\%) and Ukraine (30.8\%), with the highest for Italy (84.6\%) and Portugal (87.5\%). On average, the European P. vulgaris germplasm from the 12 geographic origins was $62 \%$ of Andean origin, 25.8\% of Mesoamerican origin and $12.2 \%$ of mixed origin (summarised from Fig. 4b).
For comparative purposes, the global PCoA distribution for all 33 loci for the accessions from the 12 geographic origins are presented in Fig. 4c. The first three axes for the PCoA cumulatively explain $73.5 \%$ of the genetic variability (Fig. 4c; data shown for first two axes only).

The global structure analysis for the geographic origins on the PvSh1 loci formed five genetic clusters $(0.623 \leq$ $\left.H_{e} \geq 0.8028\right)$ that joined the accessions from the mixed origins (attributed to the most likely genetic group of origin according to the highest $\mathrm{Q}$ value in a structure plot) (Fig. 5).

\section{Genetic potential for association mapping studies}

Four loci suitable for association mapping ( $P v \mathrm{M} 04$, $P v$ M21, SSR-IAC62, SSR-IAC66) and two loci related to angular leaf spot/ anthracnose resistance ( $P v$ M95, SSRIAC167) were included in the present study. Ten genetic 
Table 3 Geographic details and genotypic summary statistics of the accessions for the 33 loci

\begin{tabular}{|c|c|c|c|c|c|c|c|c|}
\hline $\begin{array}{l}\text { Geographic } \\
\text { origin }\end{array}$ & $\begin{array}{l}\text { Number } \\
\text { of } \\
\text { accessions }\end{array}$ & $\begin{array}{l}\text { Allelic } \\
\text { richness } \\
(A r)\end{array}$ & $\begin{array}{l}\text { Number of } \\
\text { genetic } \\
\text { clusters (real } \\
\text { K) }\end{array}$ & $\begin{array}{l}\text { Expected } \\
\text { heterozygosity } \\
\left(H_{e}\right) \text { across } \\
\text { clusters } \\
\end{array}$ & $\begin{array}{l}\text { Allele } \\
\text { frequency } \geq \\
5 \%\end{array}$ & $\begin{array}{l}\text { Global unbiased } \\
\text { expected } \\
\text { heterozygosity of } \\
\text { accessions }\end{array}$ & $\begin{array}{l}\text { Principle } \\
\text { coordinate } \\
\text { analysis (first three } \\
\text { axes) (\%) }\end{array}$ & $\begin{array}{l}\text { Mean polymorphic } \\
\text { information content } \\
\text { among all loci }\end{array}$ \\
\hline Albania & 24 & 6.369 & 5 & $0.676-0.681$ & 3.515 & 0.626 & 67.7 & 0.569 \\
\hline $\begin{array}{l}\text { Bosnia and } \\
\text { Herzegovina }\end{array}$ & 56 & 7.690 & 6 & $0.739-0.805$ & 4.939 & 0.783 & 71.0 & 0.746 \\
\hline Bulgaria & 19 & 1.794 & 7 & $0.778-0.779$ & 5.788 & 0.794 & 69.3 & 0.724 \\
\hline Hungary & 277 & 16.653 & 3 & $0.747-0.764$ & 5.242 & 0.815 & 68.5 & 0.815 \\
\hline Italy & 20 & 4.699 & 11 & $0.808-0.809$ & 6.061 & 0.815 & 65.6 & 0.761 \\
\hline Poland & 18 & 4.066 & 11 & $0.805-0.807$ & 6.273 & 0.816 & 63.6 & 0.761 \\
\hline Portugal & 8 & 1.791 & 9 & $0.745-0.747$ & 5.909 & 0.791 & 68.2 & 0.683 \\
\hline Romania & 14 & 6.330 & 5 & $0.754-0.755$ & 5.091 & 0.746 & 62.8 & 0.725 \\
\hline Serbia & 218 & 16.678 & 9 & $0.804-0.809$ & 5.121 & 0.797 & 73.5 & 0.769 \\
\hline Slovenia & 97 & 10.405 & 5 & $0.788-0.774$ & 5.152 & 0.816 & 69.0 & 0.788 \\
\hline Spain & 11 & 1.786 & 8 & $0.787-0.789$ & 5.030 & 0.786 & 66.0 & 0.715 \\
\hline Ukraine & 20 & 1.793 & 10 & $0.772-0.773$ & 5.939 & 0.793 & 63.7 & 0.723 \\
\hline
\end{tabular}

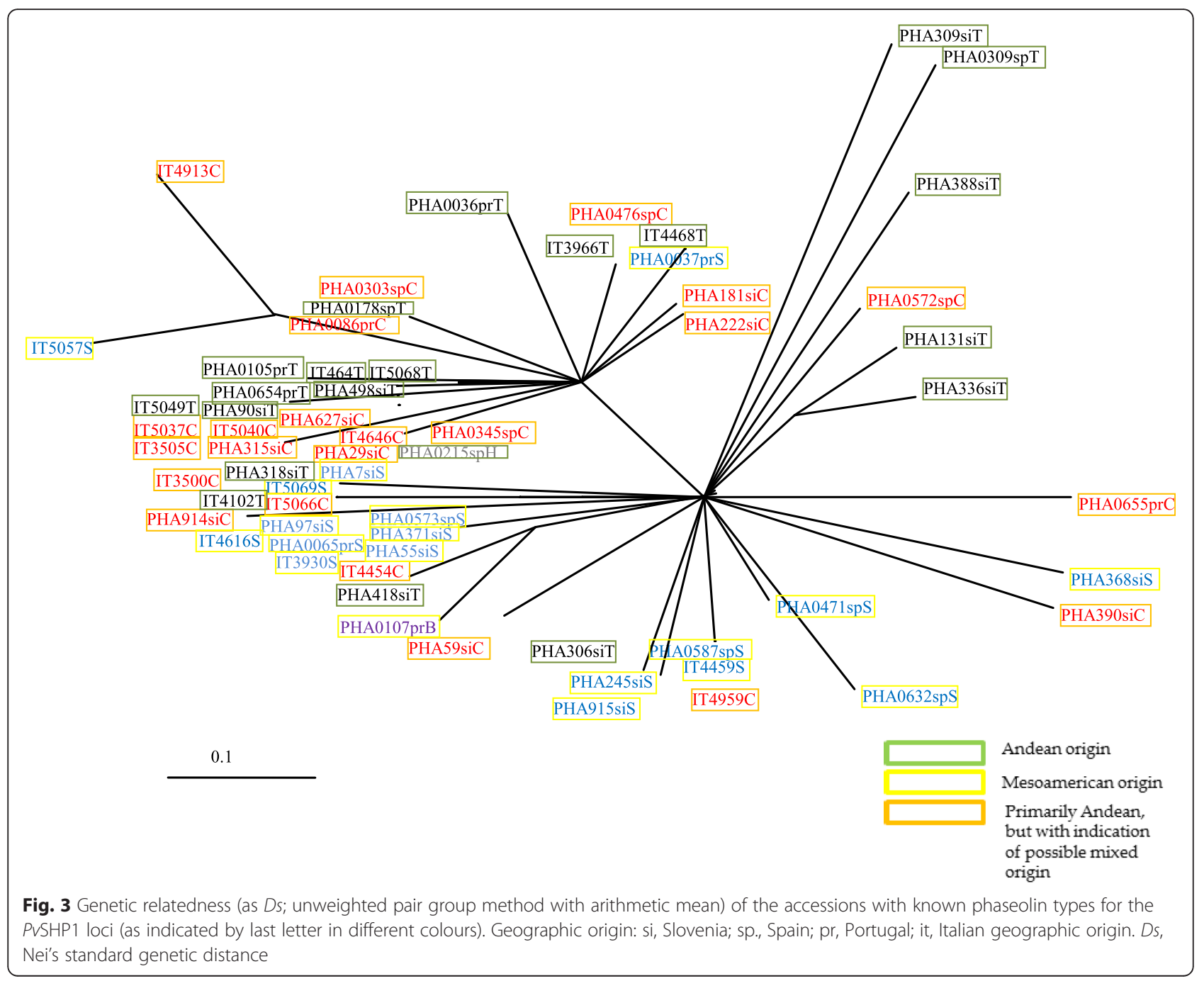




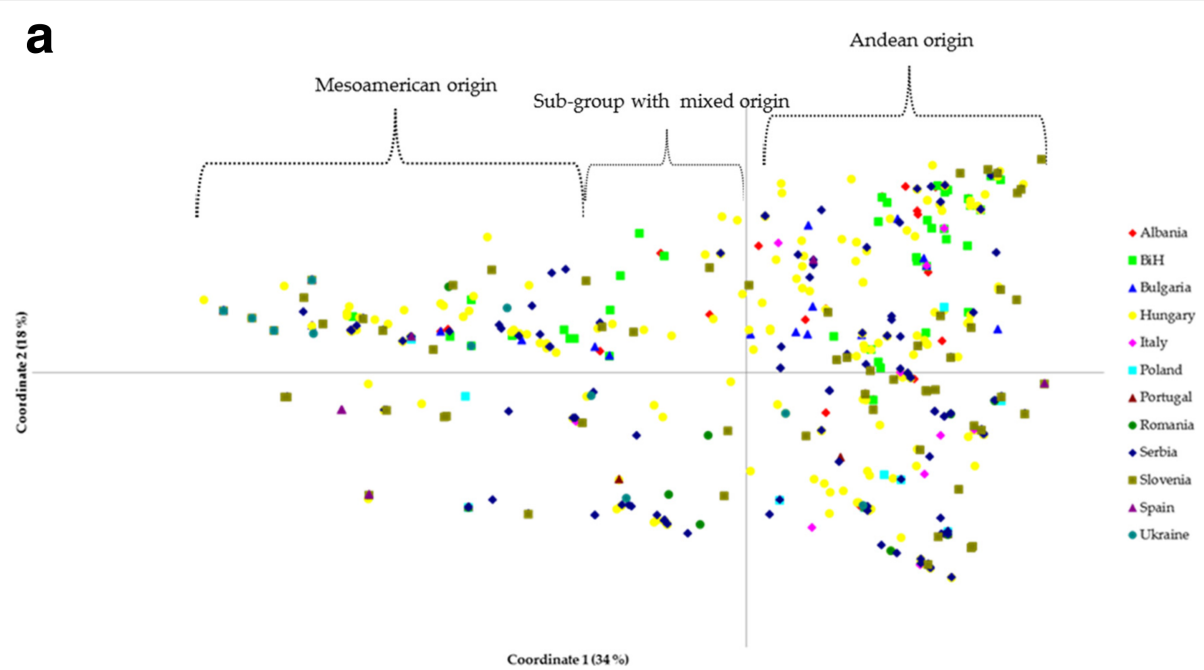

b

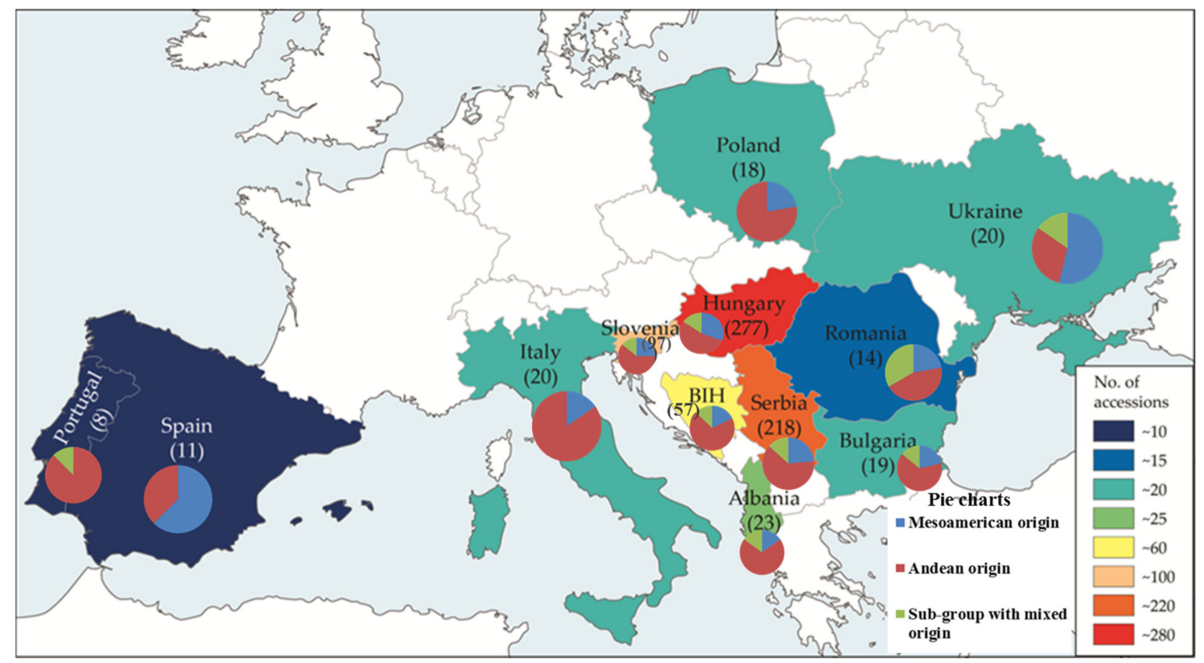

C

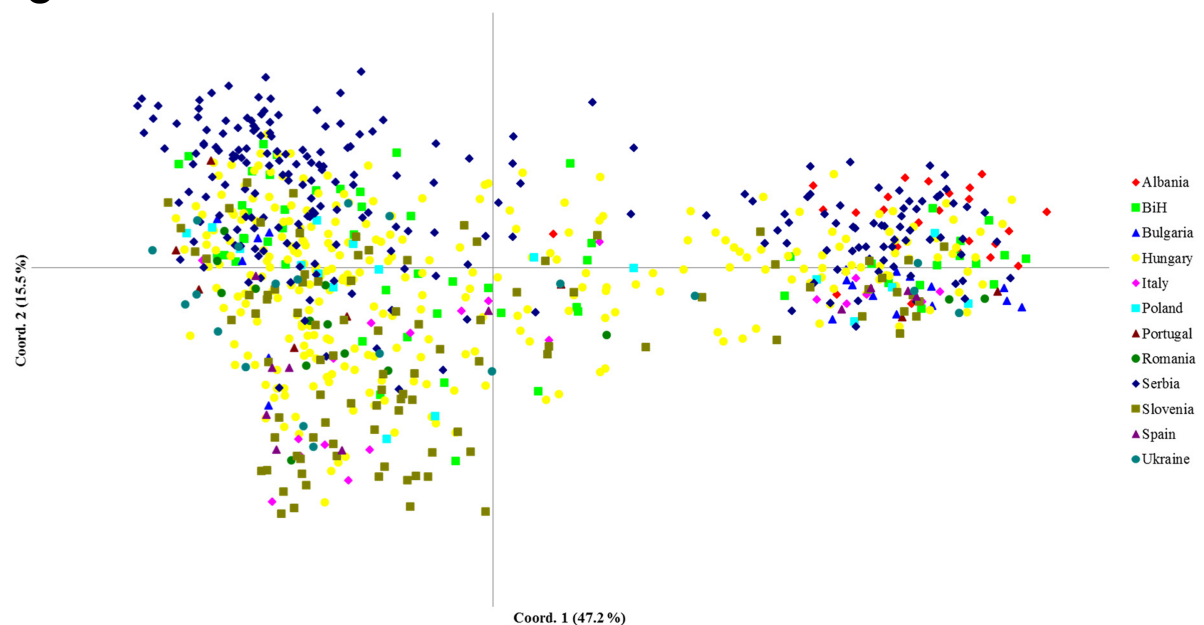

Fig. 4 a Principal coordinate analysis distribution for the PVSHP1 markers for the accessions from the 12 geographic origins. b Map with pie charts showing breakdown of the three sub-groups for each country on the basis of PVHP1 markers including number of assessed accessions within each geographic origin (in brackets). Source of map: https:/www.morevectors.com/administrative-europe-map-vector/. c Global principal coordinate analysis distribution for all 33 loci for the accessions from the 12 geographic origins 


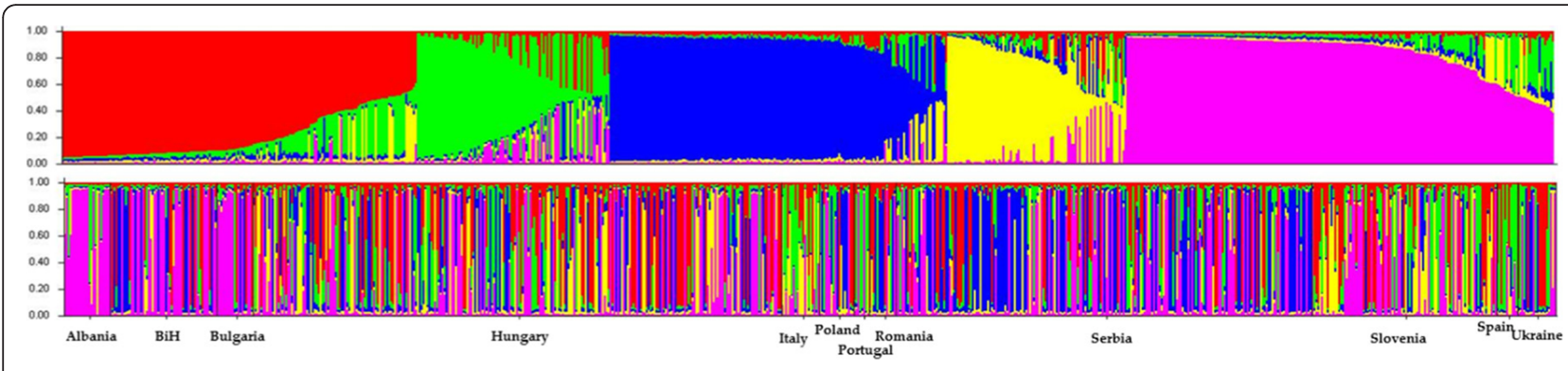

Fig. 5 Global structure plot of the accessions sorted by Q value (top), and for their genetic structure sorted by geographic origin (bottom) on the PvSh1 loci. BIH, Bosnia and Herzegovina. Each vertical bar represents the individual genotype; the colour within each bar represents the colour of different genetic cluster

clusters were formed here, with the accessions either subdivided into the geographic groups of the 782 accessions $\left(0.7808 \leq H_{e} \geq 0.7951\right)$ or not $\left(0.8308 \leq H_{e} \geq\right.$ $0.8437)$. No statistically significant deviations from $H W E$ $(p>0.05)$ were seen for loci PvM04, PvM21 and SSRIAC167 for the Italy accessions, $P v$ M21, SSR-IAC62 and $P v \mathrm{M} 95$ for the Poland accessions, PvM04, PvM21, $P v \mathrm{M} 95$ and SSR-IAC66 for the Portugal accessions, and $P v \mathrm{M} 21$ and $P v \mathrm{M} 95$ for the Spain accessions.

The highest numbers of alleles with a frequency $\geq 5 \%$ were detected within the Portugal (6.500), Poland (6.500), Italy (6.333) and Bulgaria (6.167) accessions. The highest numbers of effective alleles were obtained for the Poland $(N e=6.227)$ and Hungary $(N e=6.155)$ accessions. The lowest numbers of both allele frequency $\geq 5 \%$ (4.000) and $\mathrm{Ne}$ (3.382) were seen for the Albania accessions. No private alleles were detected within the Ukraine, Romania and Portugal accessions. In contrast, the highest numbers of private alleles $(N p)$ were seen for the Hungary (3.667), Serbia (2.500) and Slovenia (1.667) accessions, which corresponded to the highest numbers of accessions included. The highest numbers of locally common alleles were seen for the Slovenia (4.167), Hungary (4.000), Serbia (3.500), Poland (3.167) and Bosnia and Herzegovina (3.167) accessions. According to the trait-associated markers, the least genetically diverse were the accessions from Albania $\left(H_{e}=0.648 ; u H_{e}=0.663\right)$, Romania $\left(H_{e}=0.709 ; \quad u H_{e}=0.736\right)$ and Bosnia and Herzegovina $\left(H_{e}=0.712 ; u H_{e}=0.719\right)$. The accessions with the highest diversity potential for association mapping studies were from Italy $\left(H_{e}=0.812 ; u H_{e}=0.834\right)$, Spain $\left(H_{e}=0.771\right.$; $\left.u H_{e}=0.809\right)$ and Slovenia $\left(H_{e}=0.793 ; u H_{e}=0.809\right)$ (Table 4). These statistics and the data in Table 4 were calculated for the accessions that originated from each country/ geographic origin and are not compatible with the genetic clusters calculated on the basis of the genetic structure of all of the origins together. Here, we calculated the allelic pattern(s) within each country to compare the population statistics parameters among these European countries, not to compare the genetic clusters conducted from these
European countries. So, these analyses follow different points of view in terms of the data presented: on a global scale with no prior information (Fig. 1) or with prior information on the geographic origins (Fig. 2), or analysis of the allelic patterns on the segmented/ national levels separately for each country (Table 4). Moreover, Table 3 summarises the data for the trait-related loci only, to show the complete data and geographic details for all 33 loci, as calculated for each country separately.

\section{Discussion}

The first major achievement in this study was to obtain a high number of highly diverse accessions that represented the core $P$. vulgaris germplasm from western-toeastern areas of southern Europe. Considering the criteria used for the selection (i.e., geographic origin, biological status, ancestral data, phenotypic seed characteristics, phaseolin type), a collection of 782 accessions from 12 geographic origins was formed. This represents a rich source of agronomically important traits that have adapted to European growth conditions.

Our data show that high levels of $P$. vulgaris genetic diversity are maintained within the European gene banks. Three genetic clusters were identified within the $P$. vulgaris accessions kept in nine gene banks, which corresponded to three subgroups considering the main P. vulgaris origins: Mesoamerican, Andean and a subcluster with mixed origins. To confirm this, the mean diversity levels between the accessions within each subcluster only varied from 0.738 to 0.772 . The nine European gene banks included in the study are actually preserving the $P$. vulgaris germplasm according to the relative equality of the Mesoamerican and Andean gene pools. In contrast, 10 genetic clusters were generated when none of the information on the gene banks or the geographic origins was used to subdivide the accessions. The key point for interpretation of the results on the numbers of clusters from different observations is the different prior input information and data processing for the genetic structure analyses. The data for both of these 
Table 4 Allelic patterns (main values) across the accessions from the different geographic origins for the trait-related loci

\begin{tabular}{|c|c|c|c|c|c|c|c|c|}
\hline \multirow[t]{2}{*}{ Geographic origin } & \multirow{2}{*}{$\begin{array}{l}\text { Allele } \\
\text { frequency } \geq \\
5 \%\end{array}$} & \multirow{2}{*}{$\begin{array}{l}\text { Number of } \\
\text { effective alleles } \\
(\mathrm{Ne})\end{array}$} & \multirow{2}{*}{$\begin{array}{l}\text { Shannon's } \\
\text { information } \\
\text { index (I) }\end{array}$} & \multirow{2}{*}{$\begin{array}{l}\text { Number of } \\
\text { private alleles } \\
(N p)\end{array}$} & \multicolumn{2}{|c|}{$\begin{array}{l}\text { Number of locally } \\
\text { common alleles }\end{array}$} & \multirow{2}{*}{$\begin{array}{l}\text { Expected } \\
\text { heterozygosity } \\
\left(H_{e}\right) \text { across } \\
\text { clusters }\end{array}$} & \multirow{2}{*}{$\begin{array}{l}\text { Expected unbiased } \\
\text { heterozygosity }\left(u H_{e}\right) \\
\text { across clusters }\end{array}$} \\
\hline & & & & & $\leq 25 \%$ & $\leq 50 \%$ & & \\
\hline Albania & 4.000 & 3.382 & 1.424 & 0.833 & 0.667 & 2.000 & 0.648 & 0.663 \\
\hline Bosnia and Herzegovina & 4.000 & 4.964 & 1.728 & 1.500 & 1.167 & 3.167 & 0.712 & 0.719 \\
\hline Bulgaria & 6.167 & 5.855 & 1.722 & 0.167 & 0.667 & 2.000 & 0.767 & 0.787 \\
\hline Hungary & 4.667 & 6.155 & 1.941 & 3.667 & 1.667 & 4.000 & 0.757 & 0.758 \\
\hline Italy & 6.333 & 5.967 & 1.920 & 0.333 & 1.333 & 3.000 & 0.812 & 0.834 \\
\hline Poland & 6.500 & 6.227 & 1.819 & 0.333 & 0.833 & 3.167 & 0.762 & 0.784 \\
\hline Portugal & 6.500 & 4.697 & 1.560 & 0.000 & 0.833 & 2.167 & 0.723 & 0.771 \\
\hline Romania & 5.167 & 4.543 & 1.560 & 0.000 & 0.833 & 1.833 & 0.709 & 0.736 \\
\hline Serbia & 4.833 & 5.440 & 1.869 & 2.500 & 1.333 & 3.500 & 0.762 & 0.764 \\
\hline Slovenia & 4.833 & 5.802 & 2.000 & 1.667 & 1.833 & 4.167 & 0.793 & 0.797 \\
\hline Spain & 4.500 & 4.900 & 1.754 & 0.833 & 1.167 & 2.333 & 0.771 & 0.809 \\
\hline Ukraine & 5.667 & 4.951 & 1.667 & 0.000 & 0.833 & 2.500 & 0.724 & 0.743 \\
\hline
\end{tabular}

cluster analyses revealed high levels of genetic diversity throughout the whole set of these 782 European accessions. $H_{e}$ among the accessions within each gene cluster varied from 0.6814 to 0.8116 , which comprised the Mesoamerican and Andean subclusters, plus the subcluster with putative hybrids from both of these gene pools. This distribution was confirmed by the FCA. The key point of the FCA was to define the overall/ general genetic diversity among the individuals summarised using the multivariate method through presentation of the distribution pattern of the 782 accessions without any prior information (such as phaseolin type, phylogenetic relations). This FCA generated three main groups that were assigned as Mesoamerican, Andean and mixed on the basis of the standard accessions with known types of phaseolin (63 accessions), as an orientation point to classify which group is which. This FCA has no direct connection with the phylogram in Additional file 2: Figure S2, which was performed on the basis of the genetic relationships (i.e., Nei's standard genetic distances) combined with the UPGMA clustering method, thus with a different algorithm used compared with the FCA. Here we see in particular that these two different algorithms generated three main groups that can be defined as Mesoamerican, Andean and mixed (not assigned in Additional file 2: Figure S2, with the aim being to illustrate the phylogenetics of the whole 782 accessions). To compare these data to previous studies, Maras et al. [23] described two large clusters that corresponded to two gene pools of origin for accessions from the western Balkans. The comparison in the present study indicates that the accessions from both the western and eastern parts of Europe introduced different alleles, which thus increased the $P$. vulgaris diversity. This is also reflected by the third subgroup for the molecular data for the present study, which showed mixed Mesoamerican and Andean origins.

\section{Marker diversity and their applicability within this western-to-eastern European $P$. vulgaris collection}

The set of 33 SSR markers used in the present study have been shown to be polymorphic, species-specific and informative for distinguishing polymorphisms through the Mesoamerican and Andean germplasm [9, 37-44]. These markers have different repeat motifs and cover all of the linkage groups of the $P$. vulgaris genome. In general, the selected set of SSR markers was highly applicable and proved useful to detect the high diversification levels of these European accessions $\left(P I C=0.800 ; H_{e}=0.822\right)$ and to define the gene-pool structure. Indeed, when looking at data from a previous study, the overall PIC (as a general measure of marker diversity) of 104 wild $P$. vulgaris accessions and 606 cultivated genotypes using 36 loci (as a combination of both genomic and gene-based markers, as in the present study) was 0.64 (as calculated for wild and cultivated accessions) [48]. In comparison, when 13 loci were used, the germplasm from the western Balkans related to a western-to-eastern European line was more genetically uniform, as seen by the lower values of the diversity parameters among the loci $\left(P I C=0.72 ; H_{e}=0.76\right)$ [16]. Moreover, based on 26 SSR loci, $H_{e}$ for Croatia landraces was reported as 0.572 [7]. Then for a set of 123 SSR markers (SSR-IAC series), the PIC varied from 0.05 to 0.83 when screened for $20 P$. vulgaris cultivated genotypes [40]. The high $A r$ in the present study (mean, 22.767) as a fundamental measure of the genetic variation reflects the heterogeneity of the European common bean germplasm. Consequently, the $F$ might indicate the undetected null alleles (e.g., at loci ATA016, BM157) resulted in excess 
heterozygosity (e.g., at locus BM210). The set of SSR markers applied here was most informative for the Hungary and Slovenia accessions. Similarly, for the Hungary, Portugal, Serbia and Slovenia accessions only, all of the loci showed significant deviation from HWE ( $p<$ 0.05). This situation indicates that a set of these 33 loci would be applicable to effectively investigate the $P$. vulgaris germplasm.

\section{Genetic structure and level of diversification among this western-to-eastern European $P$. vulgaris germplasm} Despite the high levels of genetic variability of the $P$. vulgaris germplasm in the present study (i.e., 10 genetic clusters), only $4 \%$ of the molecular variability was found among the 12 geographic origins from these western-toeastern European areas, with $8 \%$ among the accessions and $89 \%$ within the accessions, and with $97 \%$ of the molecular variability maintained within the European gene banks.

The present study shows that on the basis of Nei's genetic identity matrix (for pairwise comparisons) [454], the diversification line of the European $P$. vulgaris germplasm follows from the western parts of southern Europe (Portugal, Spain, Italy, Slovenia) to the eastern parts, where it includes three geographically separated subgroups: the northern subgroup (Poland, Ukraine, Romania), the southern subgroup (Albania, Bulgaria) and the central subgroup (Bosnia and Herzegovina, Serbia, Hungary). The Mesoamerican common bean landraces probably arrived in Europe through Spain and Portugal in the year 1506, and the Andean in a similar way in 1528, after the exploration of Peru by Pizarro [7, 49]. The common bean is distributed throughout Europe, Asia and Africa, where it presents similarities to the Mesoamerican and Andean gene pools, and hybrids have formed between these two gene pools [7, 23, 50, 51]. Maras et al. [23] reported that for the western Balkan countries, their Macedonia accessions were evenly spread across both of these gene pools, which might indicate that $P$. vulgaris was introduced into the western Balkans mainly from the Mediterranean basin. With no reference to the number of accessions from each geographic origin, higher levels of genetic diversity were detected within the Hungary, Italy, Poland and Slovenia accessions, considering that $u H_{e}>0.800$ and $A r>4.000$. These accessions might therefore be identified for conservation purposes. The highest numbers of genetic clusters $(K \geq 9)$ were seen for Portugal, Serbia, Ukraine, Italy and Poland, which revealed the highest levels of genetic diversity among the accessions that originated from these geographic areas.

On the basis of the genetic structure, the most genetically admixture accessions were from Hungary, where only three genetic clusters were seen. For the PCoA for the Romania accessions, the lower proportion of molecular variability seen via the covariance distance matrix (62.8\%) was explained by the first three axes, which reflected the minor significance of the distribution of these accessions, compared to other geographic origins.

For the global analysis using the three PvSHP1 markers, five genetic clusters were seen, which revealed one subgroup for each gene pool (i.e., Mesoamerican, Andean) and a common subgroup that comprised accessions from mixed origins (possible putative hybrids). This finding can be briefly confirmed by the genetic relatedness of the accessions with known phaseolin type, where five groups were also defined by the phylogram obtained. The typical Andean phaseolin type $\mathrm{T}$ was distinguished from the Mesoamerican type $\mathrm{S}$ with few exceptions (i.e., IT4102T, PHA0107prB, PHA418siT). When specifying the population of geographic origin, the PvSHP1 markers distinguished among the whole collection between the Mesoamerican and Andean gene pools. Moreover, this showed that the Andean accessions are more prevalent than the Mesoamerican ones within some specific geographic origins. The global distributions of the accessions using no prior information revealed three main groups that again represented the Mesoamerican, Andean and mixed groups for the whole western-to-eastern European P. vulgaris germplasm. The combination of the PvSHP1 markers was therefore the only efficient analysis to show the detailed gene-pool affiliations of these European accessions (with $P \nu \mathrm{SHP}-1 \mathrm{~B}$ as the most distinguishing locus), especially for the central-eastern part of Europe. In contrast, the P $\nu \mathrm{SHP} 1$ $\mathrm{C}$ locus was not informative for the Bulgaria, Albania and Portugal accessions, and similarly, the PvSHP1-A locus was not informative for the Spain accessions. As seen from these data, which PvSHP1 is applied for which geographic origin within the European $P$. vulgaris germplasm is important. Hence, a few well-chosen SSR markers are better for discerning gene-pool affiliations than many SSRs. The geographic origin and informativity/ usefulness of the PvSHP1 markers applied in the present study reflect the data shown in Fig. 4a and in the pie charts in Fig. 4b. Combining all three markers of the European common bean germplasm was useful to distinguish their origins according to the Mesoamerican, Andean and mixed groups. The present study showed that this European common bean germplasm was mostly Andean, with an exception for two of the border countries here: Spain (western Europe) and Ukraine (southern Europe). As suggested by Nanni et al. [9], these three $P \nu$ SHP1 indel-spanning markers are useful for germplasm identification, and particularly to trace the distributions of the domesticated Mesoamerican and Andean gene pools. These three markers were the molecular markers that highlighted the polymorphism among the different common bean genotypes due to the 
presence/ absence of indels in the PvSHP1 gene sequence. The data from the three PvSHP1 markers successfully indicated the gene-pool origins of the European accessions (as seen from Fig. 4a, b). As a comparison, when using the whole set of the 33 markers, the global PCoA distribution was extracted in detail considering the geographic origin of each accession from the individual countries (as seen from Fig. 4c). Hence, additional information is presented to show the variability of the accessions among these European countries.

Nowadays, technology allows thousands of SNP markers to be genotyped through many genomes [52-54]. Recently, Blair et al. published a study where describe recombination and linkage disequilibrium in the $P$. vulgaris genome using a 768-marker array of SNPs based on Trans-legume Orthologous Group genes along with an advanced-generation Recombinant Inbred Line reference mapping population (BAT93 x Jalo EEP558) and an internationally available diversity panel [55]. Genebased (SSR) markers are important for genome-wide association studies [56]. Even though SSRs are still important from a candidate gene approach, they are not in a genome-wide association studies paradigm. In the present study, out of the whole set of 33 SSR markers, six SSR markers were selected as trait/ gene-related markers that are suitable for association mapping studies. These were included in the study of Perseguini et al. [57], who developed a common bean core collection of $500 P$. vulgaris accessions. For these (with 58 SSRs), the mean PIC was only 0.29. In the present study, for the Spain, Slovenia and Italy accessions, the levels of genetic diversity were high due to the highest $u H_{e}$ and $H_{e}$ values seen. The highest genetic potential for association mapping studies was calculated for the Hungary, Serbia and Slovenia accessions considering the alleles that were specific for the accessions from each of these geographic origins (i.e., the $N p$ values). On the basis of chloroplast markers and two unlinked nuclear loci (PvSHP1), Angioi et al. [58] estimated that a relatively high proportion of the European bean germplasm (about 44\%) was derived from hybridisation between the Mesoamerican and Andean gene pools. The data from the present study that was conducted on the basis of nuclear assessments show that the highest proportion of the accessions was of Andean origin. On the other hand, there were indications of subgrouping from the Mesoamerican and Andean gene pools on the basis of the PvSHP1 markers, where five genetic clusters were defined for this western-to-eastern European germplasm. As a comparison, Sinkovič et al. [59] reported that on the basis of only 14 morphological characteristics of the seeds, the $P$. vulgaris and $P$. coccineus germplasm from a gene bank in Slovenia (which also reflects its origin) consisted of three groups.

\section{Conclusions}

The data from the present study show that this collection of 782 accessions that originated along a westernto-eastern line of countries through southern Europe represents a valuable source of genetic variability. These have known backgrounds, which is generally useful for further genetic studies and for formation of a core collection that comprises the most promising accessions from these different geographic origins. Furthermore, we have shown that the 33 genome and gene-specific SSR markers used are highly applicable for diversification studies of European $P$. vulgaris accessions, and have sufficient power to distinguish between and within the Mesoamerican and Andean germplasms. Moreover, three indel-spanning markers of the P $\nu \mathrm{SHP} 1$ gene are shown here to be efficient and informative for determination of the gene-pool affiliations of these European accessions. We have also shown that these European gene banks have successfully maintained, and are sharing, this highly diverse European $P$. vulgaris germplasm for scientific and applicative purposes.

We have shown here that both the Mesoamerican and Andean accessions came to Europe following a westernto-eastern line through southern Europe. During this spread, they adapted to the European agro-climatic environment, which is reflected in the increased diversification levels that include mixed subgroups of Mesoamerican and Andean accessions and alleles that are specific for each geographic origin. However, any conclusions relating to adaptation need to be drawn up with care given the study questions and the analyses that were carried out, whereby the only clues in this regard should come from new analyses. As a perspective of the present study, the use of Approximate Bayesian Computation modelling can be recommended to check the estimates from this study. Another perspective would be the use of newer approaches. Cortes et al. [54] identified 84 gene-based SNP markers, and they detected slightly higher intra-population diversity within the Andean gene pool compared to that within the Mesoamerican gene pool. However, they emphasised that SSR markers are still essential to determine stratification, parental polymorphisms and the evolutionary processes that have occurred within each gene pool [54]. Additionally, Galeano et al. [55] reported on the discovery of SNPs in candidate genes or transcript sequences (i.e., expressed sequence tags), which has been a recurrent strategy in plant genetics mainly because gene-based SNP markers can themselves be causative SNPs for traits that are mainly formed for the Andean diversity panel of $P$. vulgaris. Such gene-based SNP markers from both of these previous studies might be particularly useful for analysis of the European P. vulgaris germplasm, where the Andean genotypes are dominant. 


\section{Methods}

Initial screening based on multi-crop passport descriptors We used the web-based EURISCO for the Phaseolus database, with the identification of $>800$ accessions that covered diverse environments from different parts of the European continent, following from Spain to Ukraine, along a western-to-eastern line of southern European countries, with Poland included in the sampling. The available data related to basic multi-crop passport descriptors and the seed characteristics were acquired from different national gene-bank curators, including geographic origin, biological status, ancestral data, phenotypic seed characteristics, phaseolin type (corresponding to Mesoamerican/ Andean origins), and seed material.

The plant material was available in limited amounts, with 9 to 32 seeds received for each accession, depending on the gene-bank availability. Out of these $>800$ accessions identified, we succeeded in acquiring 782 accessions based on certain gene-bank availability and the viability of the requested accession. Each 'accession' represented a population or genotype, which included cultivars, commercial varieties and landraces. The original sources of the plant material were the following gene banks: AIS (Slovenian and Albanian accessions), IBGR-UNI-BL (Bosnia and Herzegovina), CPD (Hungary), CSIC (Spain), DAB (Italy), IHAR (Poland), IPK (Germany), and IRP-NS (Serbia). All of the accessions included in the study are listed in Additional file 4: Table S1. The seed material was transferred via Seed Material Transfer Agreements for research purposes within the L4-7520 Project. These documents are available from the authors.

\section{Plant material and DNA extraction}

Young plants were grown in a greenhouse at the Agricultural Institute of Slovenia (latitude, $46^{\circ} 06^{\prime}$; longitude, $14^{\circ} 51^{\prime}$; altitude, $320 \mathrm{~m}$ a.s.l.). Before sowing, six seeds from each accession were chemically disinfected with $5 \%$ sodium hypochlorite. At the phase of the first true leaves, $60 \mathrm{mg}$ to $100 \mathrm{mg}$ fresh and healthy plant tissue was sampled. The extraction procedure for DNA was performed as described by Pipan et al. [27, 30] and Maras et al. [23]. The DNA concentrations of each of the isolates were determined using a fluorimeter (Qubit 3.0; ThermoFisher Scientific, MA, USA), with the DNA diluted to the final uniform concentration of $5.6 \mathrm{ng} / \mu \mathrm{L}$. A $P$. coccineus accession was included as an outgroup accession (i.e., PHA220, from Slovenia). Accessions with available data on phaseolin type were used as internal standards or anchors, to assure the correct gene-pool assignment. These included the Mesoamerican S, M and B phaseolin types, and the Andean T, C and $\mathrm{H}$ phaseolin types. The main reason why we used phaseolin-based controls rather than well-known gene pool controls, such as Andean genotypes Calima (G4494) and Chaucha
Chuga (G19833), as well as the Mesoamerican genotypes ICA Pijao (G5773) and Dorado (DOR364), is that there was the need to include and analyse accessions that were native to western and eastern European countries (e.g., Slovenia, Italy, Spain, Portugal; see accessions in Fig. 3) from where the other analysed accessions in this study came (i.e., their native geographic environment and origins).

\section{Genotyping and fragment analysis}

To define the diversification and genetic structure of the $P$. vulgaris germplasm, a set of 33 genome-specific markers were used, as developed by nine research groups $[9,37-44]$. The criterion of choice was a distribution across all of the linkage groups (i.e., 24 SSR markers). The three indel spanning markers SHP1-A, SHP1-B and SHP1-C were used for identification of the gene pool of origin [9]. Six markers from Benchimol et al., Campos et al. and Hanai et al. were used [40, 41, 43], as these were associated with specific genes (for detailed data, see Additional file 5: Table S2).

The PCR reactions were performed in a final volume of $11.5 \mu \mathrm{L}$ that contained $8.4 \mathrm{ng}$ genomic DNA and the following reagents, with initial concentrations: $1 \mu \mathrm{L}$ of 10× PCR buffer (Biotools, Spain), $0.2 \mu \mathrm{L}$ of mix from each $10 \mathrm{mM}$ dNTP (Sigma-Aldrich, ZDA), $0.5 \mu \mathrm{L} 50 \mathrm{mM}$ $\mathrm{MgCl}_{2}$ (Biotools, Spain), $0.1 \mu \mathrm{L} 10 \mu \mathrm{M}$ forward primer (Sigma-Aldrich, ZDA), $0.25 \mu \mathrm{L} 10 \mu \mathrm{M}$ reverse primer (Sigma-Aldrich, ZDA), $0.183 \mu \mathrm{L} 10 \mu \mathrm{M} 5$ '-fluorescently labelled universal primer (with 6-FAM, NED or HEX; Omega, Slovenia), and $0.5 \mu \mathrm{L} 5 \mathrm{U}$ Taq DNA polymerase (Biotools, Spain). The forward primer of each SSR had an added 18-bp tail sequence of $5^{\prime}$-TGTAAAACGACGGC CAGT-3' (M13(-21)), as described by Schuelke [60].

The PCR analyses were performed using a thermal cycler (Veriti; ThermoFisher Scientific) under the following 'touch-down' conditions, which was dependent on each primer pair: $94{ }^{\circ} \mathrm{C}$ for $4 \mathrm{~min}$; 15 cycles at $94^{\circ} \mathrm{C}$ for $1 \mathrm{~min}$; decreased temperature from $60(62){ }^{\circ} \mathrm{C}$ to $49.5(51.5){ }^{\circ} \mathrm{C}$ at $0.7{ }^{\circ} \mathrm{C}$ per cycle for $30 \mathrm{~s} ; 72^{\circ} \mathrm{C}$ for $1 \mathrm{~min}$; followed by 23 cycles at $94{ }^{\circ} \mathrm{C}$ for $30 \mathrm{~s} ; 53^{\circ} \mathrm{C}$ for $30 \mathrm{~s} ; 72^{\circ} \mathrm{C}$ for $1 \mathrm{~min}$; and final extension for $5 \mathrm{~min}$ at $72^{\circ} \mathrm{C}$. Fragment analysis was performed on a genetic analyser (3130XL; Applied Biosystems), and allele lengths were determined by comparison with an internal size standard (GeneScan-350 ROX; Applied Biosystems) using the GeneMapper 4.0 software (Applied Biosystems).

\section{Data analysis}

The following parameters were calculated using the Identity 1.0 [61] and Microsatellite-Toolkit [62] software: variability, including observed number of alleles (No); expected heterozygosity $\left(H_{e}\right)$; and polymorphic information content $(P I C)$. The following further parameters were calculated for each of the 12 geographic groups of 
accessions using the GenAlEx 6.1 software [63]: number of effective $(\mathrm{Ne})$ and private $(\mathrm{Np})$ alleles; Shannon's information index $(I)$; fixation index $(F)$; alleles with frequency $>5 \%$; number of common alleles with proportions of $\leq 25 \%$ and $\leq 50 \%$; unbiased expected heterozygosity $\left(u H_{e}\right)$; and locus-specific deviations from the Hardy-Weinberg equilibrium (HWE). The same software was used for principal coordinate analysis (PCoA). Analysis of molecular variance (AMOVA) was performed to determine the genetic variation within and among the groups of accessions (geographic origin, gene-bank origin) using the Arlequin software [64]. Due to the application of well-established markers, the frequency of null alleles is not presented, while the amplification was true and unmasked. Preliminary calculations showed that there was no need to present the results about null alleles among the loci. Moreover, other summary statistics for the markers and the population diversity parameters (e.g., Fstatistics, genetic distances, $H W E$, and others) did not show any disturbances that might be influenced by significant levels of null alleles. The estimation of gene flow for each geographic origin was carried out by calculation of the effective numbers of migrants using the private allele method of Slatkin [46] and the Genepop 4.1.0 software [65], which reported the corrected estimated value of Barton and Slatkin [47]. The Populations 1.2.28 software [66] was used for computation of Nei's standard genetic distances [45] from the allele frequencies, and for construction of the unweighted pair group method with arithmetic mean (UPGMA) dendrogram in the cluster analysis under bootstrapping (100 times). The UPGMA dendrogram was visualised using the TreeView software [67]. The dendrogram was rooted with $P$. coccineus, which was not originally defined as an outgroup as it was treated the same as the $P$. vulgaris accessions, while outgroups give polarity to unrooted trees and allow reconstruction of the ancestral character states and areas [68]. Statgraphics Centurion XVI (2009) was used to define the dendrogram of genetic relatedness between the geographic origins, using squared Euclidian methods and Ward's algorithm under bootstrapping (100 times). The Structure 2.3.3 software [69] was used to infer the population structure using a Bayesian approach, explained by the posterior probability that each accession belonged to each genetic cluster ( $Q$ value). Twenty independent runs for each $K$ (from 1 to 15 ) were performed for the admixture model, with a burning period of 10,000 followed by 100,000 Markov chain Monte Carlo repeats. The real $K$ value was selected based on the increase in the likelihood ratios between runs, using the Evanno delta $K$ statistic [70], and implemented in the Structure Harvester software [71]. An accession was assigned to a specific cluster when its percentage of membership was between
80 and $100 \%$. When using the Structure software, different information for the specifying of the numbers of populations (origins) was used in the input matrices (i.e., without specifying the population or geographic origin [only one/ European origin]; using the information for the gene-bank origins [eight gene-bank origins]; and specifying the geographic origin [12 geographic origins]) under the same criteria for choosing the optimum number of clusters for the different kinds of analysis performed. Global factorial correspondence analysis (FCA) and linkage disequilibrium between the accessions from the different geographic origins were carried out using the Genetix 4.05 software [72], and the allelic richness $(A r)$ for accessions within each geographic origin were obtained using the FSTAT 2.9.3.2 software [73]. Specific datasets were standardised before the calculations where needed, to avoid any impact of set size.

\section{Supplementary information}

Supplementary information accompanies this paper at https://doi.org/10. 1186/s12870-019-2051-0.

Additional file 1: Figure S1. Structure plot of the 782 accessions.

Additional file 2: Figure S2. Phylogenetic relationships for the complete set of accessions, based on Nei's standard genetic distances and the UPGMA clustering method.

Additional file 3: Figure S3. Genetic structure of the accessions, specifying their population of origin.

Additional file 4: Table S1. Accessions used in the present study. Additional file 5: Table S2. SSR markers applied in the present study. Additional file 6: Table S3. Analysis of molecular variance considering the gene-bank origins of the accessions.

Additional file 7: Table S4. Loci without statistically significant deviations from HWE $(p>0.05)$.

\section{Abbreviations}

AMOVA: Analysis of molecular variance; Ar: Allelic richness; F: Fixation index; FCA: Factorial correspondence analysis; $H_{e}$ : Expected heterozygosity; HWE: Hardy-Weinberg equilibrium; I: Shannon's information index; Ne: Number of effective alleles; Np: Number of private alleles; Pc: Phaseolus coccineus; PCoA: Principal coordinate analysis; PIC: Polymorphic information content; PV: Phaseolus vulgaris; SSRs: Simple sequence repeats; $\mathrm{HH}_{e}$ : Unbiased expected heterozygosity; UPGMA: Unweighted pair group method with arithmetic mean

\section{Acknowledgements}

The authors acknowledge the following gene banks for kindly supplying the plant materials used in this study: AIS (Slovenia, Albania), IBGR-UNI-BL (Bosnia and Herzegovina), CPD (Hungary), CSIC (Spain), DAB (Italy), IHAR (Poland), IPK (Germany), and IRP-NS (Serbia). We would also like to thank Marko Maras and Jelka Šuštar-Vozlič for assistance in the selection of the accessions. We are grateful to Aleš Sedlar and Aleksandra Savić for initial technical support with the DNA extractions. Finally, we would also like to thank the two anonymous reviewers for their thoughtful comments and valuable suggestions to help us to improve our manuscript.

\section{Authors' contributions}

Conceptualisation, VM, BP; plant identification, VM, BP; methodology, BP; software, BP; validation, VM, BP; formal analysis, BP; investigation, BP; resources, VM; data curation, $\mathrm{BP}$; writing - original draft preparation, $\mathrm{BP}$; writing - review and editing, VM; visualisation, BP; supervision, VM; project 
administration, BP; funding acquisition, VM both authors have read and approved the final manuscript.

\section{Funding}

This research was funded partially by the Slovenian Ministry of Agriculture, Forestry and Food and the Slovenian Research Agency, grants number P40072 and L4-7520, respectively. Under the applicative research project L47520 we have designed the study and collection, performed analyses including data interpretation. The funding under Agrobiodiversity research pregame P4-0072 covered the whole writing procedure of the manuscript.

\section{Availability of data and materials}

The datasets supporting the conclusions of this study are included here and the Supplementary Materials.

\section{Ethics approval and consent to participate}

Not applicable.

\section{Consent for publication}

Not applicable.

\section{Competing interests}

The authors declare that they have no competing interests.

Received: 17 April 2019 Accepted: 23 September 2019

Published online: 23 October 2019

\section{References}

1. Bellucci E, Bitocchi E, Rau D, Rodriguez M, Biagetti E, Giardini A, et al. Genomics of origin, domestication and evolution of Phaseolus vulgaris. In: Tuberosa R, Graner A, Frison E, editors. Genomics of Plant Genetic Resources. Berlin: Springer; 2014. p. 483-507. https://doi.org/10.1007/978-94007-7572-5_20.

2. Ganesan K, Xu B. Polyphenol-rich dry common beans (Phaseolus vulgaris L) and their health benefits. Int J Mol Sci. 2017;18:2331. https://doi.org/10. 3390/ijms18112331.

3. ECPGR. European Search Catalogue for Plant Genetic Resources. http:// eurisco.ecpgr.org. Accessed 15 Jul 2018.

4. Gepts P, Debouck D. Origin, domestication, and evolution of the common bean (Phaseolus vulgaris L.) In: Van Schoonhoven A, Voysest O. Common Beans: Research for Crop Improvement. CAB Int: Wallingford, UK and CIAT, Cali 1991. 7-53.

5. Bitocchi E, Rau D, Bellucci E, Rodriguez M, Murgia ML, Gioia T, Santo D, Nanni L, Attene G, Papa R. Beans (Phaseolus ssp.) as a model for understanding crop evolution. Front. Plant Sci. 2017:8:722. https://doi.org/10. 3389/fpls.2017.00722

6. Bitocchi E, Bellucci E, Giardini A, Rau D, Rodriguez M, Biagetti E, et al. Molecular analysis of the parallel domestication of the common bean (Phaseolus vulgaris) in Mesoamerica and the Andes. New Phytol. 2013;197: 300-13. https://doi.org/10.1111/j.1469-8137.2012.04377.x.

7. Carović-Stanko K, Liber Z, Vidak M, Barešić A, Grdiša M, Lazarević B, Šatović Z. Genetic diversity of Croatian common bean landraces. Front Plant Sci. 2017:8:604. https://doi.org/10.3389/fpls.2017.00604

8. Raggi L, Tiranti B, Negri V. Italian common bean landraces: diversity and population structure. Genet Res Crop Evol. 2013;60:1515-30. https://doi.org/ 10.1007/s10722-012-9939-y.

9. Nanni L, Bitocchi E, Bellucci E, Rossi M, Rau D, Attene G, Gepts P, Papa R. Nucleotide diversity of a genomic sequence similar to SHATTERPROOF (PvSHP1) in domesticated and wild common bean (Phaseolus vulgaris L.) Theor Appl Genet. 2011;123(8):1341-57.

10. Rendón-Anaya M, et al. Genomic history of the origin and domestication of common bean unveils its closest sister species. Gen Biol. 2017;18(1):60.

11. Beebe S, Toro O, González AV, Chacón MI, Debouck DG. Wild-weed crop complexes of common bean (Phaseolus vulgaris L., Fabaceae) in the Andes of Peru and Colombia, and their implications for conservation and breeding. Genet Resour Crop Evol. 1997;44:73-91.

12. Payró de la Cruz E, Gepts P, Colunga GarcíaMarín P, Zizumbo-Villareal D. Spatial distribution of genetic diversity in wild populations of Phaseolus vulgaris L. from Guanajuato and Michoacán, México. Genet Res Crop Evol. 2005;52:589-99.
13. Martínez-Castillo J, Zizumbo-Villarreal J, Gepts P, Delgado-Valerio P, ColungaGarcíaMarín P. Structure and genetic diversity of wild populations of Lima bean (Phaseolus lunatus L.) from the Yucatan peninsula, Mexico. Crop Sci. 2006:46:1071-80.

14. Worthington M, Soleri D, Gepts P. Genetic composition and spatial distribution of farmer-managed Phaseolus bean plantings: an example from a village in Oaxaca. Mexico Crop Sci. 2012;52:1721-35.

15. Ariani A. Mier y Teran JCB, Gepts P. spatial and temporal scales of range expansion in wild Phaseolus vulgaris. Mol Biol Evol. 2017;35(1):119-31.

16. Cortés AJ, Chavarro MC, Madriñán S, This D, Blair MW. Molecular ecology and selection in the drought-related Asr gene polymorphisms in wild and cultivated common bean (Phaseolus vulgaris L.). BMC Genet. 2012;13.1:58.

17. Cortés AJ, This D, Chavarro C, Madriñán S, Blair MW. Nucleotide diversity patterns at the drought-related DREB2 encoding genes in wild and cultivated common bean (Phaseolus vulgaris L.). Theor Appl Genet. 2012;125. 5:1069-85.

18. Cortés AJ, Monserrate FA, Ramı'rez-Villegas J, Madriñán S, Blair MW. Drought tolerance in wild plant populations: the case of common beans (Phaseolus vulgaris L.). PLoS ONE. 2013;8(4):e62898. https://doi.org/10.1371/journal.pone. 0062898.

19. Blair MW, Cortés AJ, This D. Identification of an ERECTA gene and its drought adaptation associations with wild and cultivated common bean. Plant Sci. 2016:242:250-9.

20. Cortés AJ, Blair MW. Genotyping by sequencing and genome-environment associations in wild common bean predict widespread divergent adaptation to drought. Front Plant Sci. 2018;9:128. https://doi.org/10.3389/ fpls.2018.00128

21. Cortés AJ, Skeen P, Blair MW, Chacón-Sánchez MI. Does the genomic landscape of species divergence in Phaseolus beans coerce parallel signatures of adaptation and domestication? Front Plant Sci. 2018;9:1816. https://doi.org/10.3389/fpls.2018.01816.

22. Spataro $G$, et al. Genetic diversity and structure of a worldwide collection of Phaseolus coccineus L. Theor Appl Gen. 2011;122(7):1281-91.

23. Maras M, Pipan B, Šuštar Vozlič J, Meglič $V$, et al. Examination of genetic diversity of common bean from the western Balkans. J Am Soc Hortic Sci. 2015:140(4):308-16.

24. Meglič V, Pipan B. Spatial and temporal assessment of Brassica napus L. maintaining genetic diversity and gene flow potential: an empirical evaluation. London: IntechOpen; 2018. p. 27-44. https://www.intechopen. com/books/brassica-germplasm-characterization-breeding-and-utilization/ spatial-and-temporal-assessment-of-brassica-napus-I-maintaining-genet icdiversity-and-gene-flow-pote

25. Sinkovič L, Pipan B, Meglič V, Kunstelj N, Nečemer M, Zlatić E, Žnidarčič D. Genetic differentiation of Slovenian sweet potato varieties (Ipomoea batatas) and effect of different growing media on their agronomic and nutritional traits. Ital J Agron. 2017;12(4):350-6. https://doi.org/10.4081/ija. 2017.949.

26. Pipan B, Šuštar Vozlič J, Meglič V. Cultivation, varietal structure and possibilities for cross-pollination of Brassica napus L. in Slovenia. Acta Agric Slov. 2011;97(3):247-58.

27. Pipan B, Šuštar Vozlič J, Meglič V. Genetic differentiation among sexually compatible relatives of Brassica napus L. Genetika. 2013;45(2):309-27. https://doi.org/10.2298/GENSR1302309P.

28. Šuštar Vozlič J, Maras M, Zupin M, Sedlar A, Zadražnik T, Razinger J, Kidrič M, Vodnik D, Pipan B, Meglič V. Genetic, proteomic and physiological background for breeding common bean for abiotic stress resistance. In: Plant breeding: the art of bringing science to life. Abstracts, 20th EUCARPIA General Congress, 2016, Zurich, Switzerland. Zurich: Agroscope; Kölliker, R(ur.), Boller, B. 2016. p. 299.

29. Pipan B, Žnidarčič D, Kunstelj N, Meglič V. Genetic evaluation of sweet potato accessions introduced to the central European area. J Agr Sci Tech. 2017;19(5):1139-50.

30. Pipan B, Žnidarčič D, Meglič V. Evaluation of genetic diversity of sweet potato [lpomoea batatas (L.) lam.] on different ploidy levels applying two capillary platforms. J Hortic Sci Biotechnol. 2017:92(2):192-8. https://doi.org/ 10.1080/14620316.2016.1249963.

31. Rusjan D, Pelengić R, Pipan B, Or E, Javornik B, Štajner N. Israeli germplasm: phenotyping and genotyping of native grapevines (Vitis vinifera L.). Vitis. 2015:54:87-9.

32. Rusjan D, Pipan B, Pelengić R, Meglič V. Genotypic and phenotypic discrimination of grapevine (Vitis vinifera L.) varieties of the 'Vitovska' and 'Garganja' denominations. Eur J Hortic Sci. 2012;77(2):84-94. 
33. Campa A, Murube E, Ferreira J. Genetic diversity, population structure, and linkage disequilibrium in a Spanish common bean diversity panel revealed through genotyping-by-sequencing. Genes. 2018;9(11):518.

34. Nadeem MA, Habyarimana E, Çiftçi V, Nawaz MA, Karaköy T, Comertpay G, Ercişli S. Characterization of genetic diversity in Turkish common bean gene pool using phenotypic and whole-genome DArTseq-generated silicoDArT marker information. PLoS One. 2018;13(10):e0205363. https://doi.org/10. 1371/journal.pone.0205363.

35. Smýkal P, Nelson MN, Berger JD, von Wettberg EJB. The impact of genetic changes during crop domestication. Agronomy. 2018;8:119. https://doi.org/ 10.3390/agronomy8070119.

36. Caproni L, Raggi L, Tissi C, Howlett S, Torricelli R, Negri V. Multi-environment evaluation and genetic characterisation of common bean breeding lines for organic farming systems. Sustainability. 2018;10:777. https:/doi.org/10.3390/su10030777.

37. Blair MW, Buendía HF, Giraldo MC, Métais I, Peltier D. Characterization of ATrich microsatellites in common bean (Phaseolus vulgaris L.). Theor Appl Genet. 2008;118(1):91-103. https://doi.org/10.1007/s00122-008-0879-z.

38. Blair MW, Pedraza F, Buendia HF, Gaitán-Solís E, Beebe SE, Gepts P, Tohme J. Development of a genome-wide anchored microsatellite map for common bean (Phaseolus vulgaris L.). Theor Appl Genet. 2003;107(8):1362-74. https:// doi.org/10.1007/s00122-003-1398-6.

39. Gaitán-Solís E, Duque MC, Edwards KJ, Tohme J. Microsatellite repeats in common bean (Phaseolus vulgaris): isolation, characterization, and crossspecies amplification in Phaseolus ssp. Crop Sci. 2002;42(6):2128-36. https:// doi.org/10.2135/cropsci2002.2128.

40. Benchimol LL, Campos T, Carbonell SAM, Colombo CA, Chioratto AF, Formighieri EF, et al. Structure of genetic diversity among common bean (Phaseolus vulgaris L.) varieties of 429 Mesoamerican and Andean origins using new developed microsatellite markers. Genet Resour Crop Evol. 2007; 54:1747-62. https://doi.org/10.1007/s10722-006-9184-3.

41. Hanai LR, Campos T, Camargo LEA, Benchimol LL, Souza AP, Melotto M, Carbonell SAM, Chioratto AF, Consoli L, Formighieri EF, Siqueira MVBM, Tsai SM, Vieira MLC. Development, characterization, and comparative analysis of polymorphism at common bean SSR loci isolated from genic and genomic sources. Genome. 2007;50(3):266-77. https://doi.org/10.1139/G07-007.

42. Hanai LR, Santini L, Camargo LEA, Fungaro MHP, Gepts P, Tsai SM, Vieira MLC. Extension of the core map of common bean with EST-SSR, RGA, AFLP, and putative functional markers. Mol Breed. 2010;25(1):25-45. https://doi. org/10.1007/s11032-009-9306-7.

43. Campos T, Oblessuc PR, Sforça DA, Cardoso JMK, Baroni RM, Sousa ACB, Carbonell SAM, Chioratto AF, Rubiano LLB, Souza AP. Inheritance of growth habit detected by genetic linkage analysis using microsatellites in the common bean (Phaseolus vulgaris L.). Mol Breed. 2011;27:549-60.

44. Yu K, Park SJ, Poysa V, Gepts P. Integration of simple sequence repeat (SSR) markers into a molecular linkage map of common bean (Phaseolus vulgaris L.). J Hered. 2000;91(6):429-34. https://doi.org/10.1093/jhered/91.6.429.

45. Nei M. Genetic distance between populations. Am Natural. 1972;106(949):283-92.

46. Slatkin M. Gene flow in natural populations. Ann Rev Ecol Syst. 1985;16:393-430

47. Barton NH, Slatkin MA. Quasi-equilibrium theory of the distribution of rare alleles in a subdivided population. Heredity. 1986;56:409-16.

48. Blair MW, Soler A, Cortes AJ. Diversification and population structure in common beans (Phaseolus vulgaris L.). PLoS One. 2012;7(11):e49488.

49. Gioia T, Logozzo G, Attene G, Bellucci E, Benedettelli S, Negri V, Papa R, Spagnoletti ZP. Evidence for introduction bottleneck and extensive intergene pool (Mesoamerica $\times$ Andes) hybridization in the European common bean (Phaseolus vulgaris L.) germplasm. PLoS One. 2013;8:e75974. https:// doi.org/10.1371/journal.pone.0075974.

50. Chávez-Servia JL, et al. Grain Legumes. In: Tech, Rijeka, Croatia, vol. 10; 2016. p. 63439.

51. Papa R, Nanni L, Sicard D, Rau D, Attene G. The evolution of genetic diversity in Phaseolus vulgaris L. In: Motley TJ, Zerega N, Cross H, editors. Darwin's Harvest: New Approaches to the Origins, Evolution and Conservation of Crops. New York: Columbia University Press; 2006. p. 12142. https://doi.org/10.7312/motl13316-007.

52. Blair MW, Cortés AJ, Penmetsa RV, Farmer A, Carrasquilla-Garcia N, Cook DR. A high-throughput SNP marker system for parental polymorphism screening, and diversity analysis in common bean (Phaseolus vulgaris L.). Theor Appl Genet. 2013;126(2):535-48

53. Kelleher CT, Wilkin J, Zhuang J, Cortés AJ, Quintero ÁLP, Gallagher TF, Ritland K. SNP discovery, gene diversity, and linkage disequilibrium in wild populations of Populus tremuloides. Tree Genet Genomes. 2012;8(4):821-9.
54. Cortés AJ, Chavarro MC, Blair MW. SNP marker diversity in common bean (Phaseolus vulgaris L.). Theor Appl Genet. 2011;123(5):827.

55. Blair MW, Cortés AJ, Farmer AD, Huang W, Ambachew D, Penmetsa RV, et al. Uneven recombination rate and linkage disequilibrium across a reference SNP map for common bean (Phaseolus vulgaris L.). PLoS ONE. 2018;13(3):e0189597. https://doi.org/10.1371/journal.pone. 0189597

56. Galeano CH, Cortés AJ, Fernández AC, Soler Á, Franco-Herrera N, Makunde G, Blair MW. Gene-based single nucleotide polymorphism markers for genetic and association mapping in common bean. BMC Genet. 2012;13(1):48.

57. Perseguini JMKC, Silva GMB, Rosa JRBF, Gazaffi R, Marçal JF, Carbonell SAM, Benchimol-Reis LL. Developing a common bean core collection suitable for association mapping studies. Genet Mol Res. 2015;38(1):67-78.

58. Angioi SA, Rau D, Attene G, Nanni L, Bellucci E, Logozzo G, Papa R. Beans in Europe: origin and structure of the European landraces of Phaseolus vulgaris L. Theor Appl Genet. 2010;121(5):829-43.

59. Sinkovič L, Pipan B, Sinkovič E, Meglič V. Morphological seed characterization of common (Phaseolus vulgaris L.) and runner (Phaseolus coccineus L.) bean germplasm: a Slovenian gene bank example. BioMed Res. 2019;2019:1-13, ID 6376948. https://doi.org/10.1155/2019/6376948.

60. Schuelke M. An economic method for the fluorescent labeling of PCR fragments. Nat Biotechnol. 2000;18(2):233.

61. Wagner HW, Sefc KM. Identity 1.0. Vienna: Centre for Applied Genetics, University of Agricultural Sciences; 1999.

62. Park S. Microsatellite Toolkit. Department of Genetics, Trinity College: Dublin; 2001.

63. Peakall R, Smouse PE. GenAlEx 6: genetic analysis in excel. Population genetic software for teaching and research. Mol Ecol Notes. 2006;6: 288-95.

64. Excoffier $L$, Lischer $H$. Arlequin suite version 3.5: a new series of programs to perform population genetics analyses under Linux and windows. Molecular Ecol Res. 2010;10:564-7.

65. Rousset F. Genepop 4.1.0: a complete reimplementation of the Genepop software for windows and Linux. Mol Ecol Res. 2008:8:103-6.

66. Langella O. Population 1.2.28. Logiciel de genetique des populations. Laboratoire populations, genetique et evolution, Gif-sur-Yvette, France; 2002

67. Page RDM. TreeView: an application to display phylogenetic trees on personal computers. Comp Appl Biosc. 1996;12:357-8.

68. Cortés AJ. On the origin of the common bean (Phaseolus vulgaris L.). Am J Plant Sci. 2013;4(10):1998.

69. Pritchard JK, Wen X, Falush D. Documentation for STRUCTURE software: version 2.3. USA: Department of Human Genetics, University of Chicago and Department of Statistics, University of Oxford; 2009.

70. Evanno G, Regnaut S, Goudet J. Detecting the number of clusters of individuals using the software STRUCTURE: a simulation study. Mol Ecol. 2005; 14:2611-20.

71. Earl DA, von Holdt BM. STRUCTURE HARVESTER: a website and program for visualizing STRUCTURE output and implementing the Evanno method. Conserv Genet Resour. 2011:3:429-31.

72. Belkhir K, Borsa P, Goudet J, Bonhomme F. Genetix: logicel sous Windows pour la génétique des populations, version 4.02. Université de Montpellier II, Laboratorie Genome, Populations, Interactions, 1999. p.1. http://kimura.univmontp2.fr/genetix/. Accessed 11 Feb 2019.

73. Goudet J. Fstat vision (1.2): a computer program to calculate F-statistics. J Hered. 2002:86:485-6.

\section{Publisher's Note}

Springer Nature remains neutral with regard to jurisdictional claims in published maps and institutional affiliations. 